\title{
Prevalence of Adherent-Invasive Escherichia coli with fimH Gene Isolated from Iranian Patients with Ulcerative Colitis
}

\author{
Akram Sarabi Asiabar, ${ }^{1}$ Hamid Asadzade Aghdaei, ${ }^{2}$ Azar Sabokbar, ${ }^{3}$ Mohammad Reza Zali, ${ }^{4}$ and \\ Mohammad Mehdi Feizabadi ${ }^{5,6,{ }^{*}}$ \\ ${ }^{1}$ Department of Microbiology, Karaj Branch, Islamic Azad University, Karaj, Iran \\ ${ }^{2}$ Basic and Molecular Epidemiology of Gastroenterology Disorders Research Center, Shahid Beheshti University of Medical Sciences, Tehran, Iran \\ ${ }^{3}$ Department of Microbiology, Karaj Branch, Islamic Azad University, Karaj, Iran \\ ${ }^{4}$ Department of Inflammatory Bowel Disease, Research Center for Gastroenterology and Liver Disease, Shahid Beheshti University of Medical Sciences, Tehran, Iran \\ ${ }^{5}$ Department of Microbiology, School of Medicine, Tehran University of Medical Sciences, Tehran, Iran \\ ${ }^{6}$ Thoracic Research Center, Imam Khomeini Hospital, Tehran, Iran \\ "Corresponding author: Mohammad Mehdi Feizabadi, Department of Microbiology, School of Medicine, Tehran University of Medical Sciences, Tehran, Iran. Tel: \\ +98-91288955810, E-mail: mfeizabadi@tums.ac.ir
}

Received 2016 November 27; Revised 2017 April 04; Accepted 2017 April 04.

\begin{abstract}
Background: Ulcerative colitis is a kind of inflammatory bowel disease that is considered as immunological response to commensal bacteria colonizing gut lumen. Adherent-invasive Escherichia coli strains are pathogens responsible for ulcerative colitis disease. These bacteria have special virulence factors, including type 1 fimbriae, which could be involved in inflammatory bowel disease. Objectives: The present study was conducted to determine the prevalence of adherent-invasive $\mathrm{E}$. coli with fim $\mathrm{H}$ gene isolated from Iranian patients with ulcerative colitis.

Methods: Sixty intestinal biopsy samples of 30 patients with ulcerative colitis and 30 individuals without inflammatory bowel disease were examined. Biopsies from rectum, descending, ascending, terminal ileum, and colon were taken during colonoscopy. Results: All biopsy samples were cultured for isolation of E. coli strains. Using polymerase chain reaction assay, the invasive plasmid antigen $\mathrm{H}$ and invasion-association locus genes were detected from both isolated bacteria and tissue specimens to confirm the presence of adherent-invasive E. coli. The frequency of adherent-invasive E. coli with type 1 fimbriae was much higher in patients with ulcerative colitis than control subjects. Among isolated bacteria, type 1 fimbriae of adherent-invasive E. coli were detected in 53.3\% and $13.3 \%$ of ulcerative colitis patients and control subjects, respectively. In addition, from 60 biopsy samples, type 1 fimbriae were detected in $56.7 \%$ of ulcerative colitis patients but in $10 \%$ of healthy subjects.

Conclusions: Subjects without inflammatory bowel disease had a high rate of $E$. coli strains than patients with ulcerative colitis via cultivation detection. We found a high rate of type 1 fimbriae of adherent-invasive $E$. coli in ulcerative colitis patients by polymerase chain reaction assay. It appears that the presence of adherent-invasive E. coli with type 1 fimbriae in the gastrointestinal tract of patients with ulcerative colitis is more likely than previously supposed.
\end{abstract}

Keywords: Escherichia coli, Colitis, Ulcerative, Inflammatory Bowel Diseases, PCR

\section{Background}

Ulcerative colitis (UC) is known as a chronic immunemediated disease, causing inflammation and ulcers in the colon (1). The first symptom of active disease is diarrhea mixed with blood. Many parts of the body outside the intestinal tract are affected by ulcerative colitis. In fact, the initiation of UC disease is in intestinal zones with high bacterial counts $(2,3)$. The pathogenesis of UC is complicated even though its cause is still unknown. Genetic background could be a risk factor for UC disease; however, microbiota and immune system may have roles in the occurrence of the disease (4). A wide range of bacterial species is involved in the inflammation of the colon, including Enterobacteriaceae, especially Escherichia coli (5). Escherichia coli strains living in the gut are not considered to be harmful. However, numerous studies have indicated that the number of adherent-invasive E. coli (AIEC) strains in inflammatory bowel disease (IBD) patients is significantly higher than previously estimated (6).

Adherent invasive E. coli can adhere to epithelial cells and invade cytoplasmic eukaryotic infectious cells owing to type 1 fimbriae $($ fim $H$ ), invasive plasmid antigen $\mathrm{H}$ (ipaH), and invasion-association locus ( ial). Also, it can replicate into macrophages. Accordingly, it should be considered a separate pathogenic cohort triggering intestinal disease in human. Subsequently, studies proposed that AIEC can be associated with pathogenicity of IBD (7). In adherentinvasive E. coli, the fimH gene, in particular, helps in adhering and colonizing epithelial cells. 
The ability to invade intestinal cells is acquired by ipaH and $i a l$ genes. The ipaH gene exists in multiple copies located on both chromosomes, and the plasmid is in charge of release in epithelial cells (8). Recently, there are no data about the prevalence of adherent-invasive E. coli in the large bowel of patients with inflammation (9). Adherent invasive $E$. coli pathotype has been gradually involved in the etiopathogenesis of ulcerative colitis (10). A number of culture-based and molecular-based studies support the theory that adherent-invasive E. coli especially those with fimH gene are a microbiological factor effective in IBD (1113).

\section{Objectives}

The main aim of the present study was to determine the prevalence of adherent-invasive $E$. coli with fimH gene isolated from Iranian patients with ulcerative colitis.

\section{Methods}

\subsection{Patients and Tissue Samples}

In the present study, a group of biopsy samples of 60 subjects comprising 30 UC patients ( 12 males, 18 females, median age 36.9 years, age range 16 - 75 years) and 30 individuals without IBD (14 males, 16 females, median age 48.31 years, age range 19 - 76 years) were taken during colonoscopy. The study was approved by the ethics committee of Tehran University Medical Sciences.

\subsection{Microbial Identification}

Samples obtained during colonoscopy were transferred immediately into sterile vials containing either thioglycolate broth or saline (Sigma-Aldrich, Hi Media) and stored at $-20^{\circ} \mathrm{C}$. The biopsy specimens were homogenized and inoculated into Hi Chrome E. coli agar (Sigma-Aldrich, Hi Media) and incubated for 18 - 24 hours at $35 \pm 2{ }^{\circ} \mathrm{C}$. The bacteria were stored in TSB broth containing 30\% glycerol at $-70^{\circ} \mathrm{C}$ until further analysis.

\subsection{DNA Extraction from Biopsies for PCR}

Biopsies were crushed and DNA was extracted by RTP® Mycobacteria kit (Berlin, Germany).

\subsection{DNA Extraction from Culture for PCR}

Isolated bacteria were prepared for PCR amplification. The bacterial colonies were harvested and centrifuged. The sediments were suspended in $500 \mu \mathrm{L}$ of sterile deionized water, and boiled for 10 minutes. After centrifugation of the boiled samples at $19000 \mathrm{~g}$ for 5 minutes, the supernatant was used as DNA template in PCR assay (14).

\subsection{PCR Assay}

All isolates were tested for the occurrence of $i p a H, i a l$, and fimH genes using PCR. The nucleotide sequence of primers (Macrogen, Pishgam) and size of product (base pairs) for amplification of fimH, ipaH, and ial genes are displayed in Table $1(15,16)$. PCR was performed in $25 \mu \mathrm{L}$ solution comprising $5 \mu \mathrm{L}$ of master mix (Amplicon, Pishgam), $1 \mu \mathrm{L}$ of each primer $(10 \mathrm{pm} / \mu \mathrm{L}), 2 \mu \mathrm{L}$ of DNA template (50 ng), and $16 \mu \mathrm{L}$ of $\mathrm{dd}_{2} \mathrm{O}$. Subsequently, the following thermal cycling conditions were used: 5 minutes at $94^{\circ} \mathrm{C}$ and 36 cycles of amplification consisting of 30 seconds at $95^{\circ} \mathrm{C}$, 30 seconds at $56^{\circ} \mathrm{C}$, and 1 minutes at $72^{\circ} \mathrm{C}$, with 5 minutes at $72^{\circ} \mathrm{C}$ for final extension. PCR products were investigated by electrophoresis on a $1 \%$ agarose gel in $1 \mathrm{X}$ TBE buffer [10.8 $\mathrm{g}$ Tris and $5.5 \mathrm{~g}$ Boric acid, $0.5 \mathrm{M} \mathrm{Na}_{2}$ EDTA (pH 8.0)] (17).

\subsection{Statistical Analysis}

The data were evaluated by Pearson Chi-Square test. A P value $<0.05$ was considered statistically significant.

\section{Results}

Escherichia coli strains were detected from biopsy samples of 24 patients with UC (80\%) and 26 healthy controls (86.7\%). All isolated bacteria were confirmed as AIEC by biochemical tests and PCR assay. The ipaH, ial, and fimH genes were amplified by utilizing particular primers and became visible at approximate bands of 619, 320, and 150 bp on polyacrylamide gel, respectively (Figures 1, 2 and 3). Among isolated bacteria, the presence of fimH was confirmed in $53.3 \%(n=16)$ of specimens from UC patients, while $46.7 \%$ $(\mathrm{n}=14)$ were negative. Also, this gene was detected in 4 control subjects $(13.3 \%)$ while the remaining $86.7 \%(n=26)$ lacked this gene (Table 2). In addition, amongst 60 biopsy samples taken during colonoscopy, the fim $\mathrm{H}$ gene was detected in 17 (56.7\%) patients with UC and $3(10 \%)$ control subjects (Figure 3). Accordingly, 43.3\% $(n=13)$ of UC patients and $90 \%(n=27)$ of control subjects did not yield any amplicon in PCR assay (Table 3). Therefore, fim H gene in E. coli strains isolated from UC patients was more frequent than that of control population in PCR assay. Moreover, PCR assay was more reliable than cultivation. Based on the results, the association of fimH gene presence in adherentinvasive $E$. coli with UC patients was statistically significant $(\mathrm{P}<0.05)$. Also, all positive amplified fragments were sequenced.

\section{Discussion}

The link between ulcerative colitis disease and the presence of adherent-invasive E. coli carrying fimH gene has 
Table 1. Primers and Annealing Temperature for Amplification of the AIEC Genes

\begin{tabular}{|c|c|c|}
\hline Primers & Nucleotide Sequences (5' - 3') & Size of Product, bp \\
\hline \multirow{2}{*}{ fimH } & TATGGCGGCGTGTTATCTAG & \multirow{2}{*}{150} \\
\hline & CACAGGCGTCAAATAAAGCG & \\
\hline \multirow{2}{*}{ ipaH } & GTTCCTTGACCGCCTTTCCGATACCGTC & \multirow{2}{*}{619} \\
\hline & GCCGGTCAGCCACCCTCTGAGAGTAC & \\
\hline \multirow{2}{*}{ ial } & CTGGATGGTATGGTGAGG & \multirow{2}{*}{320} \\
\hline & GGAGGCCAACAATTATTTCC & \\
\hline
\end{tabular}

Table 2. The Presence of the fimH Gene of AIEC in Isolated from Two Groups (UC Patients and Control Subjects) by PCR Assay

\begin{tabular}{|c|c|c|c|}
\hline \multirow[t]{2}{*}{ Population } & \multicolumn{3}{|c|}{ fimH } \\
\hline & Positive, No.\% & Negative, No.\% & PValue \\
\hline UC, No. $=30$ & $16(53.3 \%)$ & $14(46.7 \%)$ & 0.001 \\
\hline Control, No. $=\mathbf{3 0}$ & $4(13.3 \%)$ & $26(86.7 \%)$ & 0.001 \\
\hline
\end{tabular}

Table 3. The Presence of the fimH Gene of AIEC in Biopsy Samples from Two Groups (UC Patients and Control Populations) by PCR Assay

\begin{tabular}{lcc}
\hline Population & fimH & Nositive, N.\% \\
\cline { 2 - 3 } & $17(56.7 \%)$ & Negative, N.\% \\
\hline UC, No. $=\mathbf{3 0}$ & $3(10.0 \%)$ & $13(43.3 \%)$ \\
Control, No. $=\mathbf{3 0}$ & 0.000 & $27(90.0 \%)$ \\
\hline
\end{tabular}

Figure 1. Polymerase Chain Reaction Amplification of the ipaH Gene

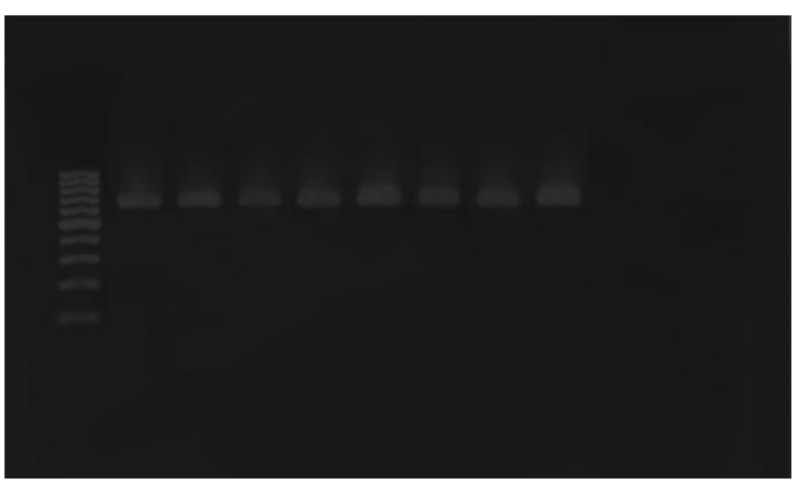

M, DNA molecular size marker (100-bp ladder); lanes 1-8, E. coli clinical isolates containing the ipaH gene (619 bp); lane 9, negative control (without DNA template).

been studied in recent years. The pattern of epidemiological characteristics and risk factors related to geographical and regional variations are still unknown (18-20). This study was carried out to determine the prevalence and possible role of AIEC with $\mathrm{fimH}$ gene in Iranian patients with UC by PCR assay since limited data are currently available
Figure 2. Polymerase Chain Reaction Amplification of the ial Gene

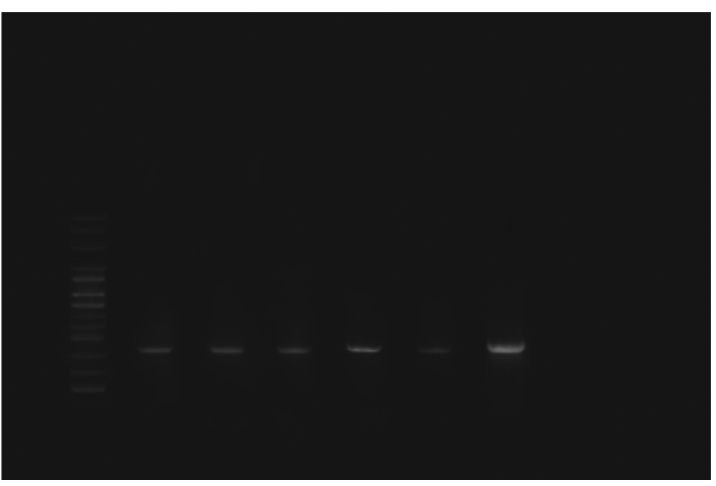

M, DNA molecular size marker (100-bp ladder); lanes 1-6, E. coli clinical isolates containing the ial gene (320 bp); lane 7, negative control (without DNA template).

on this subject. To clarify the possible colonization of AIEC in intestinal tract, we screened tissue samples for ipa $H$ and ial genes by PCR assay as these genes have been reported in many cases to be involve in AIEC invasiveness (21). However, there are other studies proposing that these genes are significant virulence determinants in many extra intestinal 
Figure 3. Polymerase Chain Reaction Amplification of the fimH Gene

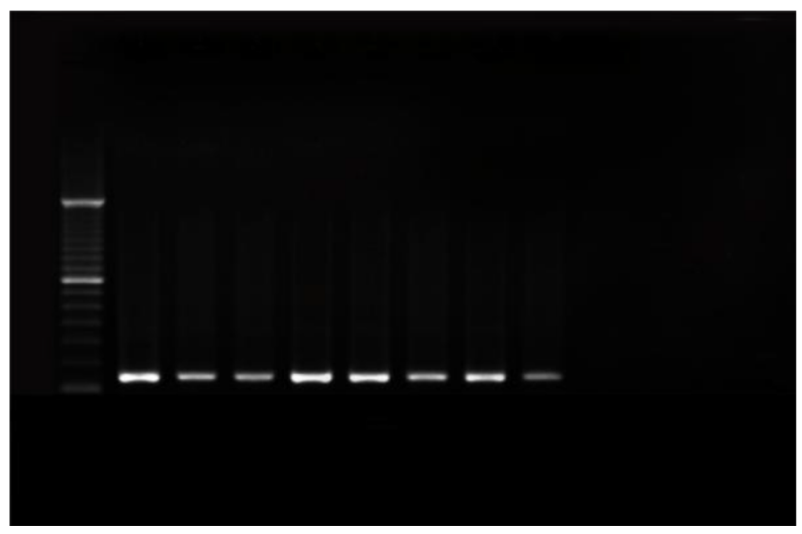

M, DNA molecular size marker (100-bp ladder); lanes 1-8, E. coli clinical isolates containing the $f \mathrm{mH}$ gene ( $150 \mathrm{bp}$ ); lane 9 , negative control (without DNA template)

infections in human, especially infections of urinary tract caused by E. coli (22).

Most studies indicate that modified microbial components and function in IBD can lead to the increased immune response. However, genetic, phenotyping, and microbial diversity within UC patients indicate that this disease is the heterogeneous cohort of different disorders, which probably has predictable natural histories (23). However, recent studies demonstrated that Entrobacteriaceae, E. coli, and Mycobacterium paratuberculosis strains are associated with IBD (24). The current study showed that there was a higher rate of fimH gene in UC patients than control subjects; a difference that was statistically significant. Despite the results of this study, some investigators did not observe any increase in AIEC among UC patients $(25,26)$.

In this regard, Raso et al. reported that AIEC was not detected in patients with UC and control subjects (27) and likewise, other studies found a higher prevalence for fimbriae I, encoded by the gene fimA, in UC patients compared to healthy individuals $(28,29)$. However, in our study, $56.7 \%$ of the patients with UC were positive for AIEC, in particular for those with fimHgen; a rate that was significantly higher than the rates reported by previous studies. Martin et al. indicated that $E$. coli is more common in patients with IBD in comparison with control people (30). It can be inferred that fim $\mathrm{H}$ gene of AIEC may trigger UC disease. But the absence of $f i m H$ gene in AIEC isolated from UC patients may indicate the point that other bacterial genera may also involve in this disease.

In many cases, several studies indicated that invasive $E$. coli strains are associated with Crohn's disease (31). Based on previous studies, AIEC strains were identified as true in- vasive strains involved in the pathogenesis of IBD. The invasive ability of AIEC, acquired by fim $H$ gene, helps its translocation to pass human intestinal barriers and move inside deep tissues $(32,33)$. In spite of the interesting debate, with the exception of assessing AIEC strains with fimH gene, this gene has been obtained in other strains of E. coli. It can be present in $68 \%$ of uropathogenic E. coli (UPEC) strains which are pathogenic in urinary tract (34). The evidence gathered proposes that adhesive and invasive $E$. coli strains could be involved in ulcerative colitis pathogenesis.

Also, limited data concerning the relation of adherentinvasive E. coli and fimHgen with UC disease in Iran are available. Therefore, we evaluated the presence of $\mathrm{fimH}$ gene of AIEC and its relation with UC disease. This study suggests that there is a possible role for this bacterium in pathogenesis of UC disease.

\subsection{Conclusion}

Several factors have been implicated in the progression of inflammatory bowel disease. In the present study, detection of AIEC with fimH gene from UC patients demonstrated that AIEC with fim $\mathrm{H}$ may be a predisposing factor in UC patients. This study provides the first clinical investigation about the relationship between AEIC, especially those with fimH gene, with ulcerative colitis disease in Tehran, Iran.

\section{Acknowledgments}

We would like to thank Behbood clinical staff for their kind cooperation. This manuscript was derived from a project supported by Tehran University of Medical Science.

\section{Footnotes}

Authors' Contribution: Mohammad Mehdi Feizabadi designed the research; Akram Sarabi Asiabar, a PhD student, did laboratory works; Hamid Asadzade Aghdaei and Mohammad Reza Zali conducted the clinical examinations and prepared the clinical specimens for culture and PCR; Azar Sabokbar was co-adviser of PhD thesis.

Funding/Support: This study was supported in part by grant No. 33309 provided by Tehran University of Medical Sciences.

\section{References}

1. Wanderas MH, Moum BA, Hoivik ML, Hovde O. Predictive factors for a severe clinical course in ulcerative colitis: Results from populationbased studies. World J Gastrointest Pharmacol Ther. 2016;7(2):235-41. doi: 10.4292/wjgpt.v7.i2.235. [PubMed: 27158539]. 
2. Dignass AU, Baumgart DC, Sturm A. Review article: the aetiopathogenesis of inflammatory bowel disease-immunology and repair mechanisms. Aliment Pharmacol Ther. 2004;20 Suppl 4:9-17. doi: 10.1111/j.1365-2036.2004.02047.x. [PubMed: 15352888].

3. Macfarlane S, Steed H, Macfarlane GT. Intestinal bacteria and inflammatory bowel disease. Crit Rev Clin Lab Sci. 2009;46(1):25-54. doi: 10.1080/10408360802485792. [PubMed:19107650].

4. Akiho H, Yokoyama A, Abe S, Nakazono Y, Murakami M, Otsuka Y, et al. Promising biological therapies for ulcerative colitis: A review of the literature. World J Gastrointest Pathophysiol. 2015;6(4):219-27. doi: 10.4291/wjgp.v6.i4.219. [PubMed: 26600980].

5. Guarner F, Malagelada JR. Role of bacteria in experimental colitis. Best Pract Res Clin Gastroenterol. 2003;17(5):793-804. [PubMed: 14507589].

6. Boudeau J, Glasser AL, Masseret E, Joly B, Darfeuille-Michaud A. Invasive ability of an Escherichia coli strain isolated from the ileal mucosa of a patient with Crohn's disease. Infect Immun. 1999;67(9):4499-509. [PubMed: 10456892].

7. Barnich N, Darfeuille-Michaud A. Adherent-invasive Escherichia coli and Crohn's disease. Curr Opin Gastroenterol. 2007;23(1):16-20. doi: 10.1097/MOG.0b013e3280105a38. [PubMed: 17133079].

8. Sousa MA, Mendes EN, Collares GB, Peret-Filho LA, Penna FJ, Magalhaes PP. Shigella in Brazilian children with acute diarrhoea: prevalence, antimicrobial resistance and virulence genes. Mem Inst Oswaldo Cruz. 2013;108(1):30-5. [PubMed: 23440111].

9. Willing B, Halfvarson J, Dicksved J, Rosenquist M, Jarnerot G, Engstrand $\mathrm{L}$, et al. Twin studies reveal specific imbalances in the mucosaassociated microbiota of patients with ileal Crohn's disease. In flamm Bowel Dis. 2009;15(5):653-60. doi:10.1002/ibd.20783. [PubMed: 19023901].

10. Baumgart M, Dogan B, Rishniw M, Weitzman G, Bosworth B, Yantiss R, et al. Culture independent analysis of ileal mucosa reveals a selective increase in invasive Escherichia coli of novel phylogeny relative to depletion of Clostridiales in Crohn's disease involving the ileum. ISME J. 2007;1(5):403-18. doi:10.1038/ismej.2007.52. [PubMed: 18043660].

11. Darfeuille-Michaud A, Neut C, Barnich N, Lederman E, Di Martino P, Desreumaux P, et al. Presence of adherent Escherichia coli strains in ileal mucosa of patients with Crohn's disease. Gastroenterology. 1998;115(6):1405-13. [PubMed: 9834268].

12. Fujita H, Eishi Y, Ishige I, Saitoh K, Takizawa T, Arima T, et al. Quantitative analysis of bacterial DNA from Mycobacteria spp., Bacteroides vulgatus, and Escherichia coli in tissue samples from patients with inflammatory bowel diseases. J Gastroenterol. 2002;37(7):509-16. doi: 10.1007/s005350200079. [PubMed: 12162408].

13. Gophna U, Sommerfeld K, Gophna S, Doolittle WF, Veldhuyzen van Zanten SJ. Differences between tissue-associated intestinal microfloras of patients with Crohn's disease and ulcerative colitis. J Clin Microbiol. 2006;44(11):4136-41. doi: 10.1128/JCM.01004-06. [PubMed: 16988016].

14. Hojati Z, Zamanzad B, Hashemzadeh M, Molaie R, Gholipour A. The FimH Gene in Uropathogenic Escherichia coli Strains Isolated From Patients With Urinary Tract Infection. Jundishapur J Microbiol. 2015;8(2):17520. doi: 10.5812/jjm.17520. [PubMed: 25825648].

15. Nguyen TV, Le Van P, Le Huy C, Gia KN, Weintraub A. Detection and characterization of diarrheagenic Escherichia coli from young children in Hanoi, Vietnam. J Clin Microbiol. 2005;43(2):755-60. doi: 10.1128/JCM.43.2.755-760.2005. [PubMed: 15695676].

16. da Cruz CB, de Souza MC, Serra PT, Santos I, Balieiro A, Pieri FA, et al. Virulence factors associated with pediatric shigellosis in Brazilian Amazon. Biomed Res Int. 2014;2014:539697. doi: 10.1155/2014/539697. [PubMed: 24877110].

17. Zhang Y, Rowehl L, Krumsiek JM, Orner EP, Shaikh N, Tarr PI, et al. Correction: Identification of Candidate Adherent-Invasive E. coli Signature Transcripts by Genomic/Transcriptomic Analysis. PLoS One. 2015;10(7):0134759. doi: 10.1371/journal.pone.0134759. [PubMed:
26218289]

18. Abraham SN, Sun D, Dale JB, Beachey EH. Conservation of the Dmannose-adhesion protein among type 1 fimbriated members of the family Enterobacteriaceae. Nature. 1988;336(6200):682-4. doi: 10.1038/336682a0. [PubMed: 2904657].

19. Klemm $P, C h r i s t i a n s e n ~ G$. Three fim genes required for the regulation of length and mediation of adhesion of Escherichia coli type 1 fimbriae. Mol Gen Genet. 1987;208(3):439-45. [PubMed: 2890081].

20. Krogfelt KA, Bergmans H, Klemm P. Direct evidence that the FimH protein is the mannose-specific adhesin of Escherichia coli type $1 \mathrm{fim}$ briae. Infect Immun. 1990;58(6):1995-8. [PubMed: 1971261].

21. Vermeire S, Van Assche G, Rutgeerts P. Laboratory markers in IBD: useful, magic, or unnecessary toys?. Gut. 2006;55(3):426-31. doi: 10.1136/gut.2005.069476. [PubMed:16474109].

22. Mitra A, Palaniyandi S, Herren CD, Zhu X, Mukhopadhyay S. Pleiotropic roles of uvrY on biofilm formation, motility and virulence in uropathogenic Escherichia coli CFT073. PLoS One. 2013;8(2):55492. doi: 10.1371/journal.pone.0055492. [PubMed: 23383333].

23. Barnich N, Carvalho FA, Glasser AL, Darcha C, Jantscheff P, Allez M, et al. CEACAM6 acts as a receptor for adherent-invasive E. coli, supporting ileal mucosa colonization in Crohn disease. J Clin Invest. 2007;117(6):1566-74. doi: 10.1172/JCI30504. [PubMed: 17525800].

24. Flanagan P, Campbell BJ, Rhodes JM. Bacteria in the pathogenesis of inflammatory bowel disease. Biochem Soc Trans. 2011;39(4):1067-72. doi: 10.1042/BST0391067. [PubMed: 21787349].

25. Florin TH, Paterson EW, Fowler EV, Radford-Smith GL. Clinically active Crohn's disease in the presence of a low C-reactive protein. Scand J Gastroenterol. 2006;41(3):306-11. doi: 10.1080/00365520500217118. [PubMed: 16497618].

26. Jiang XL, Cui HF. An analysis of 10218 ulcerative colitis cases in China. World J Gastroenterol. 2002;8(1):158-61. [PubMed: 11833094].

27. Raso T, Crivellaro S, Chirillo MG, Pais P, Gaia E, Savoia D. Analysis of Escherichia coli isolated from patients affected by Crohn's disease. Curr Microbiol. 2011;63(2):131-7. doi: 10.1007/s00284-011-9947-8. [PubMed: 21626145].

28. Gombosova L, Lazurova I, Zakuciova M, Curova K, Kmetova M, Petrasova D, et al. Genes of intestinal Escherichia coli and their relation to the inflammatory activity in patients with ulcerative colitis and Crohn's disease. Folia Microbiol (Praha). 2011;56(5):367-72. doi: 10.1007/s12223-011-0051-z. [PubMed: 21877213].

29. Boudeau J, Barnich N, Darfeuille-Michaud A. Type 1 pili-mediated adherence of Escherichia coli strain LF82 isolated from Crohn's disease is involved in bacterial invasion of intestinal epithelial cells. Mol Microbiol. 2001;39(5):1272-84. [PubMed: 11251843].

30. Martin HM, Campbell BJ, Hart CA, Mpofu C, Nayar M, Singh R, et al. Enhanced Escherichia coli adherence and invasion in Crohn's disease and colon cancer. Gastroenterology. 2004;127(1):80-93. [PubMed: 15236175].

31. Mitsuyama K, Tomiyasu N, Takaki K, Masuda J, Yamasaki H, Kuwaki K, et al. Interleukin-10 in the pathophysiology of inflammatory bowel disease: increased serum concentrations during the recovery phase. Mediators Inflamm. 2006;2006(6):26875. doi: 10.1155/MI/2006/26875. [PubMed: 17392581].

32. Barnich N, Boudeau J, Claret L, Darfeuille-Michaud A. Regulatory and functional co-operation of flagella and type 1 pili in adhesive and invasive abilities of AIEC strain LF82 isolated from a patient with Crohn's disease. Mol Microbiol. 2003;48(3):781-94. [PubMed: 12694621].

33. Sartor RB. Microbial influences in inflammatory bowel diseases. Gastroenterology. 2008;134(2):577-94. doi: 10.1053/j.gastro.2007.11.059. [PubMed: 18242222].

34. Tarchouna M, Ferjani A, Ben-Selma W, Boukadida J. Distribution of uropathogenic virulence genes in Escherichia coli isolated from patients with urinary tract infection. Int J Infect Dis. 2013;17(6):e450-3. doi: 10.1016/j.ijid.2013.01.025. [PubMed: 23510539]. 